\title{
BIOCHEMICAL RESPONSES AND SALT REMOVAL POTENTIAL OF PEGANUM HARMALA L. (WILD RUE) UNDER DIFFERENT NaCl CONDITIONS
}

\author{
KARAKAS, S. \\ Harran University, Faculty of Agriculture, Department of Soil Science and Plant Nutrition, \\ 63300 Sanliurfa, Turkey \\ (e-mail:skarakas@harran.edu.tr) \\ (Received $6^{\text {th }}$ Dec 2019; accepted $6^{\text {th }}$ May 2020)
}

\begin{abstract}
In this study, biochemical and molecular responses of Peganum harmala L. (wild rue) were investigated following $\mathrm{NaCl}$ treatment $\left(0\right.$, control-, 150 - and $\left.300 \mathrm{mmol} \mathrm{L}^{-1}\right)$ under growth room conditions. $P$. harmala seeds were placed in pots to germinate the seeds. $\mathrm{NaCl}$ application to the seedlings was done at the $4^{\text {th }}$ week of seedling growth. The plants were then respectively irrigated with $\mathrm{NaCl}$ solution for a period of 5-week. Following harvest, it was noted that fresh and dry weights of P. harmala increased with salinity levels. Chlorophyll- $a$ and $b$, proline, and malondialdehyde and hydrogen peroxide contents as well as the activity of antioxidant enzymes such as catalase and peroxidase significantly increased as a result of treatments at concentrations between 150 and $300 \mathrm{mmol} \mathrm{L}^{-1} \mathrm{NaCl}$ when compared to those of control plants $(\mathrm{P} \leq 0.05)$. The highest $\mathrm{Na}^{+}$and $\mathrm{Cl}^{-}$ions were 78.8 and $68.1 \mathrm{mg} \mathrm{g}^{-1} \mathrm{DW}$ at $300 \mathrm{mmol} \mathrm{L}{ }^{-1} \mathrm{NaCl}$, respectively. On the other hand, ion contents such as $\mathrm{K}^{+}, \mathrm{Ca}^{++}$and $\mathrm{Mg}^{++}$decreased under 150-300 mmol L-1 NaCl when compared to the control plants $(\mathrm{P} \leq 0.05)$. Removal of $\mathrm{Na}^{+}$as the adjusted removal capacity per hectare under field conditions were 304.6 and $404.2 \mathrm{~kg}$ at 150 - and $300 \mathrm{mmol} \mathrm{L}^{-1} \mathrm{NaCl}$ concentrations. DNA damage measurement showed that DNA integrity of the halophyte preserved its uniform shape at 150 - and $300 \mathrm{mmol} \mathrm{L}^{-1} \mathrm{NaCl}$ according to measurements of the results of the comet assay. This study showed that $P$. harmala could well used to clean-up highly saline soils to regain them for agricultural purposes.
\end{abstract}

Keywords: phytoremediation, salt stress, ameliorate, comet assay, DNA damage

\section{Introduction}

Salt stress in soil layers or in irrigation waters is a major threat to modern agriculture via causing inhibition and impairment of plant growth and productivity, especially in arid and semi-arid regions of the world (Hussain et al., 2009; Isayenkov and Maathuis, 2019). More than $20 \%$ of cultivated land worldwide, which is about 45 million hectares is affected by salt stress and the amount is increasing day by day (Gupta and Huang, 2014; Shrivastava et al., 2015). A soil is considered to be saline when the electric conductivity (EC) of the soil solution reaches $4 \mathrm{dS} \mathrm{m}^{-1}$ (equivalent to approximately $40 \mathrm{mmol} \mathrm{L}^{-1} \mathrm{NaCl}$ ) and it generates an osmotic pressure of about $-0.2 \mathrm{MPa}$. Under these circumstances, yields of most of the crops are significantly reduced. As a consequence, ion toxicity lead to chlorosis and necrosis mainly due to $\mathrm{Na}^{+}$accumulation that interferes with many physiological processes in plants (Munns and Tester, 2008; Rouphael et al., 2018). Under saline conditions, plants have to activate different physiological and biochemical mechanisms in order to cope with the resulting stress. Such mechanisms include changes in toxic ion uptake, ion compartmentation and/or exclusion, osmotic regulation, photosynthesis, chlorophyll content, toxic ion distribution, homeostasis, reactive oxygen species (ROS), and antioxidant metabolites and enzymes (Ashraf and Haris, 2013; Acosta-Motos et al., 2017; Carillo, 2019).

Plants on the basis of adaptive evolution can be classified as either glycophytes or halophytes (Gupta and Huang, 2014; Cheeseman, 2015). Glycophytes are not 
salt-tolerant plants, which include most of the crop plants. The survival of these plants is seriously retarded after $100-200 \mathrm{mmol} \mathrm{L}^{-1} \mathrm{NaCl}$ concentrations (Zakharin and Panichkin, 2009; Carillo et al., 2011). Halophytic plants are known to accumulate excess salts in tissues, they remove salt from the immediate environment (Simpson et al., 2018). They are naturally adapted to live in soil characterized by high salt concentrations. They do not have problems with salinity exceeding $300-400 \mathrm{mmol} \mathrm{L}^{-1}$ $\mathrm{NaCl}$. They have developed better salt resistance mechanisms as described above (Stuart et al., 2012; Cheeseman, 2015).

$P$. harmala belongs to Zygophyllaceae family, which is a perennial plant growing spontaneously in semi-arid conditions, stepp areas and sandy soils. It is native to eastern Mediterranean region. It is a shrub, 0.3-0.8 $\mathrm{m}$ tall with short creeping roots, white flowers and round seed capsules carrying more than 50 seeds. The plant is widely distributed and used as a medicinal plant in Central Asia, North Africa and Middle East (Frison et al., 2008; Wanntorp and Ronse De Craene, 2011). In this study, we aimed to determine the performance of $P$. harmala in terms of biochemical responses and $\mathrm{Na}^{+}$ ion removal capacity under different $\mathrm{NaCl}$ conditions (0, control-, 150- and $300 \mathrm{mmol}$ $\mathrm{L}^{-1}$ ) for phytoremediation purposes.

\section{Material and Methods}

\section{Experimental set up and plant growth}

Experiment was conducted at the University of Harran, Sanliurfa, Turkey. The halophyte species of $P$. harmala seeds were initially sterilized with $70 \%$ ethanol for $30 \mathrm{~s}$ and then with $0.1 \%(\mathrm{w} / \mathrm{v}) \mathrm{HgCl}_{2}$ for five min following three washes with sterile distilled water. Trials were performed in a randomized block design with three replicates. Air-dry soil was passed through 4-mm sieve for the pot experiment and 2-mm sieve for the analysis of physicochemical properties. Soil saturated paste was prepared and electrical conductivity (EC), $\mathrm{pH}$ were measured (Richards, 1954). Texture (clay, silt and sand) was determined by using Bouyoucos hydrometer method (Bouyoucos, 1953). Physicochemical properties are reported in Table 1. The seeds at batches of 10 were sown into the $1.5 \mathrm{~L}$ plastic pots containing $1 \mathrm{~kg}$ of air-dry in a growth room at $35 / 25^{\circ} \mathrm{C}$ of day/night temperature. After germination, the seedlings were irrigated with full pot capacity during this period; salt treatments were started with the irrigation water containing various concentrations of $\mathrm{NaCl}$ ( 0 (control)-, 150- and 300 mmol L ${ }^{-1}$ ) solutions (Fig. 1). The treatment continued for further 5 weeks, then the plants were harvested for the evaluation of salinity responses. For this, the harvested leaves of $P$. harmala were stored at $-22^{\circ} \mathrm{C}$ until analyses.

Table 1. Physicochemical properties of the soil

\begin{tabular}{c|c}
\hline Soil parameter & Values \\
\hline EC $\left(\mathrm{dS} \mathrm{m}^{-1}\right)$ & 1.2 \\
$\mathrm{pH}$ & 7.8 \\
Clay $(\%)$ & 56.7 \\
Silt $(\%)$ & 32.5 \\
Sand $(\%)$ & 10.8 \\
\hline
\end{tabular}




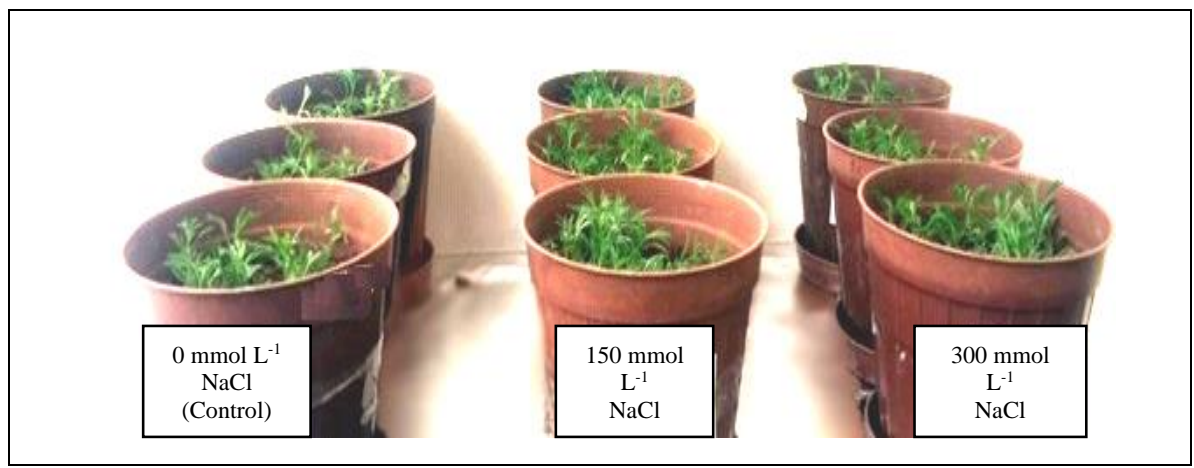

Figure 1. Growth of P. harmala at different $\mathrm{NaCl}$ conditions

\section{Growth parameters}

For the growth analysis, the fresh weight $(\mathrm{FW})$ was determined right after the harvest. The dry weight (DW) of plants was determined after drying of samples at $70^{\circ} \mathrm{C}$ until they reached a constant weight.

\section{Determination of biochemical responses}

Chlorophyll (Chl- $a$ and Chl- $b$ ) contents of $P$. harmala were determined based on the method of Arnon (1949) with slight modifications (Dikilitas, 2003). Leaf samples $(0.5 \mathrm{~g})$ were homogenized in a $10 \mathrm{~mL}$ acetone:water $(80: 20, \mathrm{v}: \mathrm{v})$ mixture and filtered through Whatman No.2 filter paper then placed in dark tubes. Chl- $a$ and Chl- $b$ of the plant samples were read at a UV microplate spectrophotometer (Epoch, SN: 1611187, made in USA) at 663-645 $\mathrm{nm}$ respectively against $80 \%$ acetone blank. The results were calculated as $\mathrm{mg} \mathrm{L}^{-1}$ and expressed as $\mathrm{mg} \mathrm{g}^{-1}$ fresh weight.

The proline (pro) measurement was conducted according to the method of Bates et al. (1973) with slight modifications (Karakas et al., 2019a). Leaf material (0.5 g) was homogenized in $3 \% \mathrm{w} / \mathrm{v}$ sulphosalicylic acid using a mortar and a pestle. The homogenate was filtered through Whatman No. 2 filter paper. Then, $2 \mathrm{~mL}$ of filtrate was mixed in a test tube with $2 \mathrm{~mL}$ of acid-ninhydrin reagent $(1.25 \mathrm{~g}$ of ninhydrin in $30 \mathrm{~mL}$ of glacial acetic acid and $20 \mathrm{~mL}$ of $6 \mathrm{M}$ phosphoric acid) and boiled at $100^{\circ} \mathrm{C}$ for one hour. The reaction was terminated in an ice bath. The reaction mixture was then extracted using $5 \mathrm{~mL}$ of toluene. The tubes were thoroughly shaken for 15-20 seconds and left for $20 \mathrm{~min}$ at room temperature in order to achieve separation for two layers. The chromophore containing toluene was removed and allowed to warm to room temperature, and the absorbance of the solution was measured at $515 \mathrm{~nm}$ using a toluene blank. Proline concentration was determined using calibration curve made with L-proline (Sigma-Aldrich 81202-06-4) as $\mu \mathrm{mol} \mathrm{g}^{-1}$ fresh tissue.

The malondialdehyde (MDA) content was determined according to the method of Sairam and Saxena (2000) with slight modifications (Karakas et al., 2019a). Leaf material $(0.5 \mathrm{~g})$ was homogenized in $10 \mathrm{ml}$ of $0.1 \%(\mathrm{w} / \mathrm{v})$ TCA solution. The homogenate was centrifuged at $10,000 \mathrm{~g}$ for five minutes. Four $\mathrm{mL}$ of $20 \% \mathrm{v} / \mathrm{v}$ TCA containing $0.5 \% \mathrm{v} / \mathrm{v}$ thiobarbituric acid (TBA) was added to one mililiter of the supernatant. The mixture was incubated in boiling water for $30 \mathrm{~min}$, and the reaction was stopped by placing the reaction tubes in an ice bath. The mixture was centrifuged again at $10,000 \mathrm{~g}$ for $5 \mathrm{~min}$ and the absorbance of the supernatant was read at 532 and $600 \mathrm{~nm}$. Here, the MDA content of leaves is expressed as nmol g${ }^{-1}$ fresh tissue (Eq. l). 


$$
\operatorname{MDA}\left(\text { nmol g }^{-1}\right)=\frac{\text { Extract volume }(\mathrm{ml}) \times\left[\left(A_{532}-A_{600}\right) /\left(155 \mathrm{mM}^{-1} \mathrm{~cm}^{-1}\right)\right]}{\text { Sample amaunt }(\mathrm{g})} \times 10^{3}
$$

Catalase enzyme activity (CAT, E.C. 1.11.1.6) was determined by monitoring the decomposition of $\mathrm{H}_{2} \mathrm{O}_{2}$ according to the method of Milosevic and Slusarenko (1996) with slight modifications (Karakas et al., 2019a). Fresh leaf tissue $(0.5 \mathrm{~g})$ was homogenized in $10 \mathrm{~mL}$ of $50 \mathrm{mmol} \mathrm{L}^{-1} \mathrm{Na}$-phosphate buffer solution, then $50 \mu \mathrm{L}$ of plant extract was added to a $2.95 \mathrm{~mL}\left(10 \mathrm{mmol} \mathrm{L}^{-1} \mathrm{H}_{2} \mathrm{O}_{2}, 50 \mathrm{mmol} \mathrm{L}^{-1}\right.$ Na-phosphate buffer and $4 \mathrm{mmol} \mathrm{L}^{-1} \mathrm{Na}_{2} \mathrm{EDTA}$ ) reaction mixture and measured for 30 seconds at $240 \mathrm{~nm}$ with a UV microplate spectrophotometer (Epoch, SN: 1611187, made in USA). One CAT activity unit (U) is defined as a change of 0.1 absorbance unit per minute. Activity is expressed as enzyme units per gram FW.

Peroxidase enzyme activity (E.C.1.11.1.7) was determined according to the method by Cvikrova et al. (1994) with slight modifications (Karakas et al., 2019a). For the analysis, $100 \mu \mathrm{L}$ of extract (obtained as above) was added to $3 \mathrm{~mL}$ of the reaction mixture $\left(13 \mathrm{mmol} \mathrm{L}^{-1}\right.$ guaiacol, $5 \mathrm{mmol} \mathrm{L}^{-1} \mathrm{H}_{2} \mathrm{O}_{2}$, and $50 \mathrm{mmol} \mathrm{L}^{-1} \mathrm{Na}$-phosphate, $\mathrm{pH}$ 6.5). The reaction was initiated with a $\mathrm{H}_{2} \mathrm{O}_{2}$ addition and was measured at $470 \mathrm{~nm}$ using a UV microplate spectrophotometer (Epoch, SN: 1611187, made in USA) at one-minute interval until $3^{\text {rd }}$ minute. One unit of POX activity was defined as a change of 0.1 absorbance unit per minute at $470 \mathrm{~nm}$. Activity is expressed as enzyme units per gram of FW.

Hydrogen peroxide levels $\left(\mathrm{H}_{2} \mathrm{O}_{2}\right)$ were determined according to Sergiev et al. (1997) with slight modifications (Karakas et al., 2019a). Fresh plant tissue $(0.5 \mathrm{~g})$ was homogenized in an ice bath with $5 \mathrm{ml} 0.1 \%$ (w:v) trichloroacetic acid (TCA). The homogenate was centrifuged at $12,000 \mathrm{~g}$ for $15 \mathrm{~min}$ at $4^{\circ} \mathrm{C}$ and $0.5 \mathrm{~mL}$ of the supernatant were added to $0.5 \mathrm{ml} 10 \mathrm{mmol} \mathrm{L}^{-1}$ potassium phosphate buffer $(\mathrm{pH} 7.0)$ and $1 \mathrm{~mL} 1 \mathrm{M}$ potassium iodide. The absorbance was read at $390 \mathrm{~nm}$ using a UV microplate spectrophotometer (Epoch, SN: 1611187, made in USA). The $\mathrm{H}_{2} \mathrm{O}_{2}$ content was calculated as $\mu \mathrm{mol} \mathrm{g}^{-1} \mathrm{FW}$.

\section{Determination of ion contents}

The ion contents $\left(\mathrm{Na}^{+}, \mathrm{K}^{+}, \mathrm{Ca}^{2+}, \mathrm{Mg}^{2+}\right)$ of leaves were determined according to the procedure of Chapman and Pratt (1961) with slight modifications (Karakas, 2013). Samples burned at $500^{\circ} \mathrm{C}$ were homogenized in $5 \mathrm{~mL}$ of a $2 \mathrm{~N} \mathrm{HCl}$. The homogenate obtained following filtration was analyzed by Inductively Coupled Plasma (ICP, Perkin Elmer). Chloride was determined by ion chromatography (IC) after the filtration through filter paper.

\section{Determination of Sodium ion Removal}

The concentration of $\mathrm{Na}^{+}$ion removed by harvested $P$. harmala was calculated according to the equation made by Qadir et al. (2003) with slight modifications (Karakas et al., 2017) (Eq. 2).

$$
S_{\text {Na-removal }}=\left[\left(S_{N a-\text { conc }}\right)\left(S_{D W}\right) /\left(10^{3}\right)\right] /\left(M W_{N a}\right)
$$


where $\mathrm{S}_{\mathrm{Na} \text {-removal }}$ is the $\mathrm{Na}^{+}$removal through harvest $\left(\mathrm{mmol} \operatorname{pot}^{-1}\right), \mathrm{S}_{\mathrm{Na} \text {-conc }}$ is the ion concentration in the harvested plant $\left(\mathrm{mg} \mathrm{kg}^{-1}\right), S_{\mathrm{DW}}$ is the plant dry weight $\left(\mathrm{g} \mathrm{pot}^{-1}\right)$, and $\mathrm{MW}_{\mathrm{Na}}$ is the molecular weight of $\mathrm{Na}^{+}$.

\section{Determination of DNA damage}

Assessment of DNA damage caused by $\mathrm{NaCl}$ was made via the comet assay method developed for plants (Gichner et al., 2004; Pourrut et al., 2015). P. harmala leaves were placed in a $60-\mathrm{mm}$ Petri dish kept on ice and spread with $250 \mu \mathrm{l}$ of cold $400 \mathrm{mmol} \mathrm{L}^{-1}$ Tris buffer, $\mathrm{pH}$ 7.5. The plate was kept tilted on ice so that the isolated leaves nuclei would collect in the buffer. Frosted-end microscope slides were dipped into a solution of $1 \%$ NMP agarose prepared with water at $50^{\circ} \mathrm{C}$, dried overnight at room temperature and kept dry in slide boxes until use. Onto each slide, nuclear suspension (50 $\mu 1)$ and $1 \%$ low melting point (LMP) agarose $(50 \mu \mathrm{l})$ prepared with phosphate-buffered saline (PBS) were added at $40^{\circ} \mathrm{C}$. The nuclei and the LMP agarose were gently mixed and $80 \mu \mathrm{L}$ aliquots were placed on microscope slides which were pre-coated with $1 \%$ normal melting point (NMP) agarose. The drops were then covered with a coverslip and the slides were placed on ice for $5 \mathrm{~min}$. Then, the coverslips were removed and the slides were placed in a horizontal gel electrophoresis tank containing freshly prepared cold electrophoresis buffer ( $1 \mathrm{mmol} \mathrm{L}^{-1} \mathrm{Na}_{2}$ EDTA and $\left.300 \mathrm{mmol} \mathrm{L}^{-1} \mathrm{NaOH}, \mathrm{pH}>13\right)$. The nuclei were incubated for $15 \mathrm{~min}$ to allow the DNA to unwind prior to electrophoresis at $0.72 \mathrm{~V} / \mathrm{cm}(26 \mathrm{~V}, 300 \mathrm{~mA})$ for $5 \mathrm{~min}$ at $4^{\circ} \mathrm{C}$. DNA damage was examined after the assay protocol in both control and $\mathrm{NaCl}$-exposed groups. The damaged DNA resembled comets when checked under a fluorescence microscopy. The intensity of the comet tail relative to the head reflected the number of DNA breaks (Collins, 2004). Tail length was assessed using a software called comet assay software program (CASP) (Konca et al., 2003).

\section{Data analysis}

Data were statistically analyzed by one-way analysis of variance (ANOVA) using the SPSS software program (Version 22.0). To separate treatment means for each measured parameter, Duncan's Multiple Range Test was performed at a significance level of $\mathrm{P} \leq 0.05$.

\section{Results}

\section{Soil properties}

Soil physicochemical properties were measured before the start the experiment. The soil properties were shown in Table 1. According to our findings, soil electrical conductivity of soil paste extract (EC) and $\mathrm{pH}$ were $1.2 \mathrm{dS} \mathrm{m} \mathrm{m}^{-1}$ and 7.8 , respectively. The soil texture was determined as clay.

With this table, we observed that the soil was suitable to accumulate excess ions due to its "clay" structure. Therefore, any improvements on this soil through phytoremediation of $P$. harmala would be a promising approach to clean up such soils. Since EC level of the soil was $1.2 \mathrm{dS} \mathrm{m}^{-1}$, which is quite suitable for agricultural purposes, it is important to determine build up toxic salt ions and their salt level is reduced. 


\section{Plant growth of P. harmala under high $\mathrm{NaCl}$ stress}

Growth parameters were determined as shoot FW and DW. At control, $0 \mathrm{mmol} \mathrm{L}^{-1}$ $\mathrm{NaCl}$ conditions, shoot FW and DW of the plants significantly decreased while at 150and $300 \mathrm{mmol} \mathrm{L}^{-1} \mathrm{NaCl}$ conditions, shoot $\mathrm{FW}$ and DW of the plants significantly increased. $P$. harmala produced almost twice as much shoot DW yield as that of $0 \mathrm{mmol} \mathrm{L}{ }^{-1} \mathrm{NaCl}$ (control) condition (Fig. $2 A$ and 2B, Table 2).

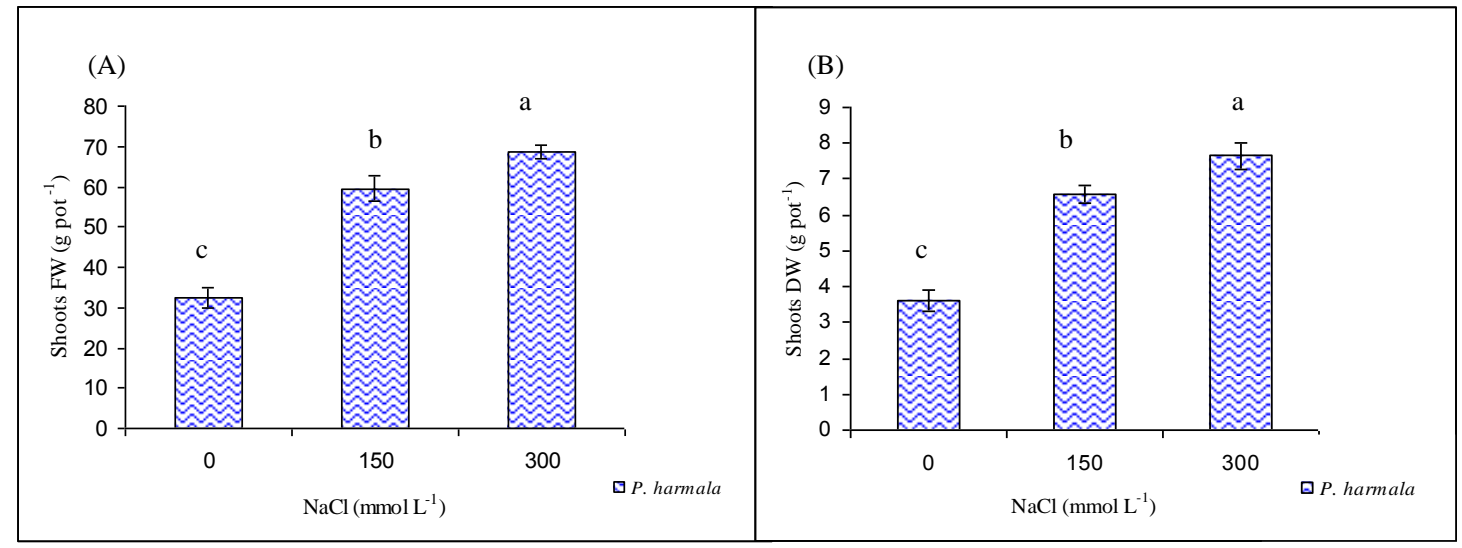

Figure 2. A) Shoots $F W$; B) Shoots DW of P. harmala plants at different $\mathrm{NaCl}$ concentrations.

Bars indicate the means of threes replicates \pm standard error. Bars with different letters indicate the significant differences from one another according to Duncan's Multiple Range Test at $P \leq 0.05$

\section{Determination of biochemical responses of $\mathrm{P}$. harmala under high $\mathrm{NaCl}$ stress}

To determine the biochemical responses of $P$. harmala, measured from the leaves of sampled plants in terms of some parameters were of chlorophyll contents (Chl- $a$, Chl- $b$ ), proline, MDA, CAT, POX and $\mathrm{H}_{2} \mathrm{O}_{2}$ levels.

Chlorophyll contents (Chl- $a$ and Chl- $b$ ) were twice as much under $150-300 \mathrm{mmol} \mathrm{L}^{-1}$ $\mathrm{NaCl}$ as the control plants growing in no salt conditions (Fig. 3A, 3B, Table 2).

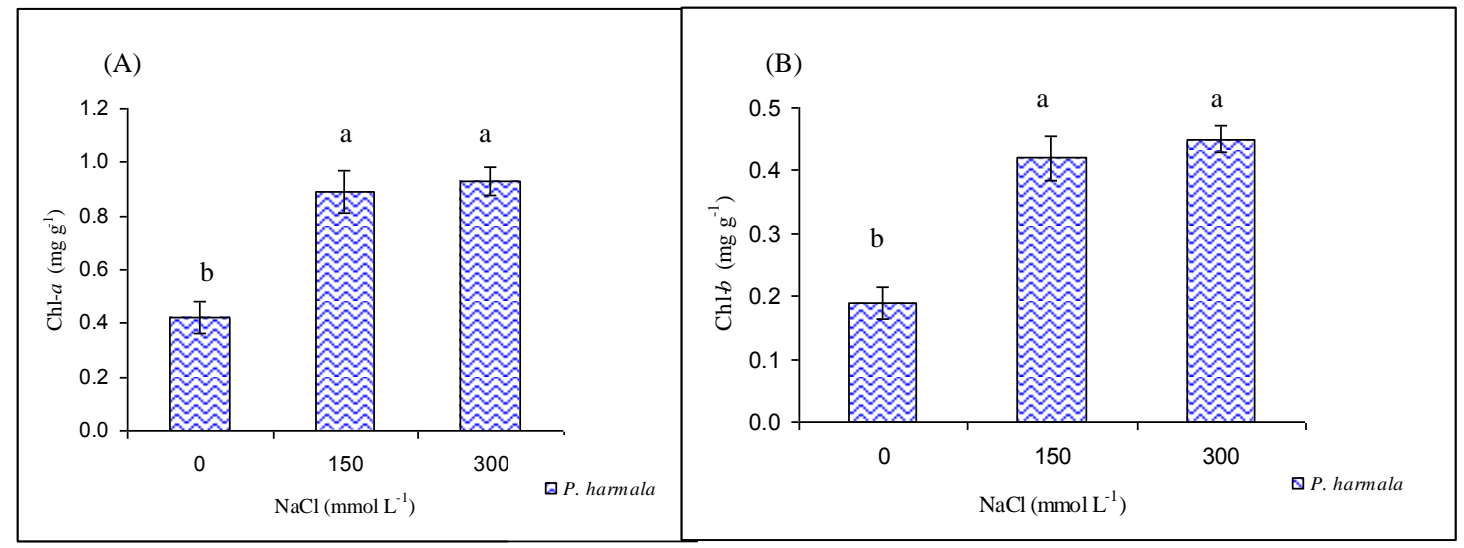

Figure 3. A) Chl-a; B) Chl-b of P. harmala plants at different NaCl concentrations. Bars indicate the means of threes replicates \pm standard error. Bars with different letters indicate significant differences from one another according to Duncan's Multiple Range Test at $P \leq 0.05$ 
Table 2. Analyses of plant parameters using ANOVA

\begin{tabular}{|c|c|c|c|c|c|}
\hline Plant parameters & Salt levels & $\mathbf{n}$ & Mean \pm S.E & $\mathbf{F}$ & Sig. \\
\hline FW & $\begin{array}{c}0 \\
150 \\
300 \\
\text { Total }\end{array}$ & $\begin{array}{l}3 \\
3 \\
3 \\
9\end{array}$ & $\begin{array}{l}32.45 \pm 2.54 \\
59.51 \pm 3.19 \\
68.21 \pm 1.67 \\
53.50 \pm 5.56\end{array}$ & 54.33 & 0.00 \\
\hline DW & $\begin{array}{c}0 \\
150 \\
300 \\
\text { Total }\end{array}$ & $\begin{array}{l}3 \\
3 \\
3 \\
9\end{array}$ & $\begin{array}{l}3.62 \pm 0.30 \\
6.60 \pm 0.25 \\
7.65 \pm 0.39 \\
5.95 \pm 0.62\end{array}$ & 43.17 & 0.00 \\
\hline Chl- $a$ & $\begin{array}{c}0 \\
150 \\
300 \\
\text { Total } \\
\end{array}$ & $\begin{array}{l}3 \\
3 \\
3 \\
9 \\
\end{array}$ & $\begin{array}{l}0.42 \pm 0.07 \\
0.89 \pm 0.09 \\
0.93 \pm 0.05 \\
0.75 \pm 0.09 \\
\end{array}$ & 16.10 & 0.00 \\
\hline Chl- $b$ & $\begin{array}{c}0 \\
150 \\
300 \\
\text { Total } \\
\end{array}$ & $\begin{array}{l}3 \\
3 \\
3 \\
9 \\
\end{array}$ & $\begin{array}{l}0.19 \pm 0.03 \\
0.42 \pm 0.04 \\
0.45 \pm 0.02 \\
0.35 \pm 0.04 \\
\end{array}$ & 26.56 & 0.00 \\
\hline pro & $\begin{array}{c}0 \\
150 \\
300 \\
\text { Total } \\
\end{array}$ & $\begin{array}{l}3 \\
3 \\
3 \\
9 \\
\end{array}$ & $\begin{array}{l}1.29 \pm 0.13 \\
3.66 \pm 0.31 \\
4.25 \pm 0.44 \\
3.07 \pm 0.48 \\
\end{array}$ & 24.24 & 0.00 \\
\hline MDA & $\begin{array}{c}0 \\
150 \\
300 \\
\text { Total } \\
\end{array}$ & $\begin{array}{l}3 \\
3 \\
3 \\
9\end{array}$ & $\begin{array}{c}6.58 \pm 0.79 \\
14.23 \pm 1.86 \\
16.72 \pm 2.00 \\
12.51 \pm 1.73 \\
\end{array}$ & 10.36 & 0.01 \\
\hline CAT & $\begin{array}{c}0 \\
150 \\
300 \\
\text { Total } \\
\end{array}$ & $\begin{array}{l}3 \\
3 \\
3 \\
9 \\
\end{array}$ & $\begin{array}{l}0.67 \pm 0.08 \\
1.14 \pm 0.10 \\
1.13 \pm 0.14 \\
0.98 \pm 0.10 \\
\end{array}$ & 5.70 & 0.04 \\
\hline POX & $\begin{array}{c}0 \\
150 \\
300 \\
\text { Total } \\
\end{array}$ & $\begin{array}{l}3 \\
3 \\
3 \\
9\end{array}$ & $\begin{array}{l}2.39 \pm 0.24 \\
4.38 \pm 0.37 \\
3.71 \pm 0.34 \\
3.49 \pm 0.33\end{array}$ & 9.89 & 0.01 \\
\hline $\mathrm{H}_{2} \mathrm{O}_{2}$ & $\begin{array}{c}0 \\
150 \\
300 \\
\text { Total } \\
\end{array}$ & $\begin{array}{l}3 \\
3 \\
3 \\
9\end{array}$ & $\begin{array}{l}3.37 \pm 0.20 \\
6.24 \pm 0.63 \\
6.31 \pm 0.69 \\
5.31 \pm 0.56 \\
\end{array}$ & 9.18 & 0.02 \\
\hline Leaf $\mathrm{Na}^{+}$ & $\begin{array}{c}0 \\
150 \\
300 \\
\text { Total } \\
\end{array}$ & $\begin{array}{l}3 \\
3 \\
3 \\
9\end{array}$ & $\begin{array}{c}3.53 \pm 0.60 \\
65.75 \pm 1.59 \\
78.80 \pm 2.41 \\
49.36 \pm 11.64\end{array}$ & 558.22 & 0.00 \\
\hline Leaf $\mathrm{K}^{+}$ & $\begin{array}{c}0 \\
150 \\
300 \\
\text { Total } \\
\end{array}$ & $\begin{array}{l}3 \\
3 \\
3 \\
9\end{array}$ & $\begin{array}{l}2.58 \pm 0.09 \\
2.21 \pm 0.12 \\
2.19 \pm 0.04 \\
2.32 \pm 0.08\end{array}$ & 6.26 & 0.03 \\
\hline Leaf $\mathrm{Ca}^{++}$ & $\begin{array}{c}0 \\
150 \\
300 \\
\text { Total }\end{array}$ & $\begin{array}{l}3 \\
3 \\
3 \\
9\end{array}$ & $\begin{array}{l}1.16 \pm 0.06 \\
0.93 \pm 0.07 \\
0.78 \pm 0.12 \\
0.96 \pm 0.07\end{array}$ & 5.20 & 0.05 \\
\hline
\end{tabular}




\begin{tabular}{|c|c|c|c|c|c|}
\hline Plant parameters & Salt levels & $\mathbf{n}$ & Mean \pm S.E & $\mathbf{F}$ & Sig. \\
\hline \multirow{4}{*}{ Leaf $\mathrm{Mg}^{++}$} & 0 & 3 & $0.27 \pm 0.01$ & \multirow{4}{*}{13.68} & \multirow{4}{*}{0.01} \\
\hline & 150 & 3 & $0.22 \pm 0.01$ & & \\
\hline & 300 & 3 & $0.21 \pm 0.01$ & & \\
\hline & Total & 9 & $0.23 \pm 0.01$ & & \\
\hline \multirow{4}{*}{ Leaf $\mathrm{Cl}^{-}$} & 0 & 3 & $7.43 \pm 1.03 \mathrm{c}$ & \multirow{4}{*}{54.78} & \multirow{4}{*}{0.00} \\
\hline & 150 & 3 & $45.25 \pm 2.96 \mathrm{~b}$ & & \\
\hline & 300 & 3 & $68.14 \pm 6.45 \mathrm{a}$ & & \\
\hline & Total & 9 & $40.28 \pm 9.09$ & & \\
\hline \multirow{4}{*}{$\begin{array}{c}\text { Removal Na }{ }^{+} \\
\left(\mathrm{mmol} \mathrm{pot}^{-1}\right)\end{array}$} & 0 & 3 & $0.57 \pm 0.13 \mathrm{c}$ & \multirow{4}{*}{70.05} & \multirow{4}{*}{0.00} \\
\hline & 150 & 3 & $21.56 \pm 1.38 \mathrm{~b}$ & & \\
\hline & 300 & 3 & $28.60 \pm 2.68 \mathrm{a}$ & & \\
\hline & Total & 9 & $16.91 \pm 4.30$ & & \\
\hline \multirow{4}{*}{$\begin{array}{c}\text { Removal Na }{ }^{+} \\
\left(\mathrm{kg} \mathrm{ha}^{-1}\right)\end{array}$} & 0 & 3 & $8.10 \pm 1.86 \mathrm{c}$ & \multirow{4}{*}{69.90} & \multirow{4}{*}{0.00} \\
\hline & 150 & 3 & $304.57 \pm 19.58 b$ & & \\
\hline & 300 & 3 & $404.17 \pm 37.88 \mathrm{a}$ & & \\
\hline & Total & 9 & $238.94 \pm 60.74$ & & \\
\hline \multirow{4}{*}{ DNA tail lenght } & 0 & 3 & $29.00 \pm 2.89 \mathrm{a}$ & \multirow{4}{*}{0.58} & \multirow{4}{*}{0.59} \\
\hline & 150 & 3 & $31.00 \pm 3.79 \mathrm{a}$ & & \\
\hline & 300 & 3 & $34.00 \pm 3.21 \mathrm{a}$ & & \\
\hline & Total & 9 & 31.331 .81 & & \\
\hline \multirow{4}{*}{ DNA damage } & 0 & 3 & $4.50 \pm 0.58 \mathrm{a}$ & \multirow{4}{*}{0.28} & \multirow{4}{*}{0.77} \\
\hline & 150 & 3 & $4.60 \pm 0.67 \mathrm{a}$ & & \\
\hline & 300 & 3 & $5.13 \pm 0.70 \mathrm{a}$ & & \\
\hline & Total & 9 & $4.74 \pm 0.34$ & & \\
\hline
\end{tabular}

Both proline and MDA contents of $P$. harmala increased at $150-300 \mathrm{mmol} \mathrm{L}^{-1} \mathrm{NaCl}$ stress conditions. At the highest $\mathrm{NaCl}$ level $\left(300 \mathrm{mmol} \mathrm{L}^{-1}\right)$, proline and MDA contents were 3.3 and 2.5 times higher, respectively than those of leaves in the control group (Fig. 4A, 4B, Table 2).

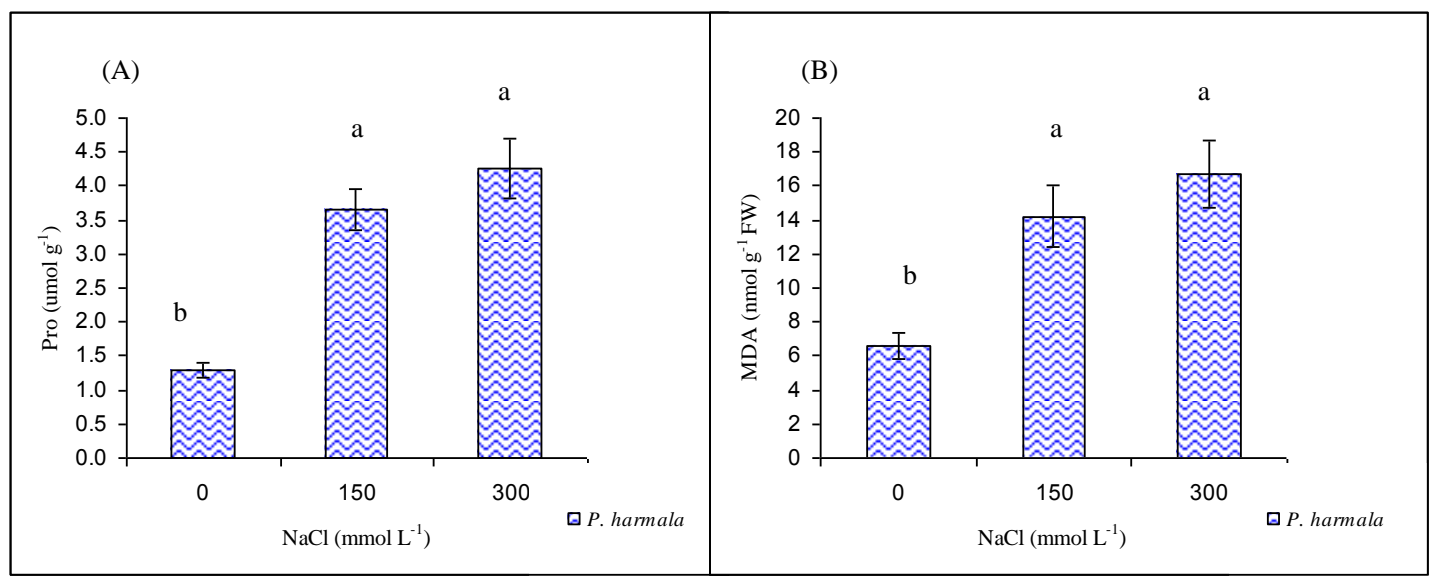

Figure 4. A) Proline (Pro); B) MDA of P. harmala plants at different NaCl concentrations.

Bars indicate the means of threes replicates \pm standard error. Bars with different letters indicate the significant differences from one another according to Duncan's Multiple Range

Test at $P \leq 0.05$ 
CAT and POX enzymes showed also increasing trend as the concentration of $\mathrm{NaCl}$ increased. At 150- and $300 \mathrm{mmol} \mathrm{L}^{-1} \mathrm{NaCl}$ concentrations, both enzymes were remarkably expressed. At $300 \mathrm{mmol} \mathrm{L}^{-1} \mathrm{NaCl}$, the expression of both enzymes were still high although slightly decreases were evident. However, this was not statistically significant (Fig. 5A and 5B, Table 2).

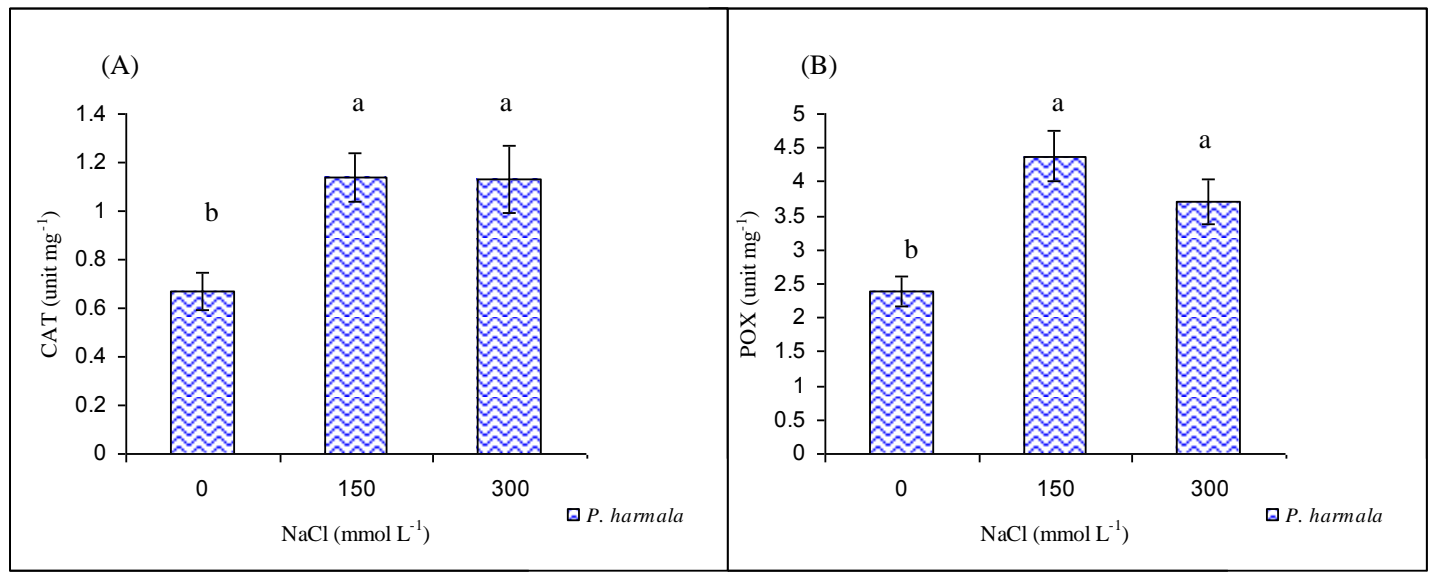

Figure 5. A) CAT; B) POX of P. harmala plants at different NaCl concentrations. Bars indicate

the means of threes replicates \pm standard error. Bars with different letters indicate the significant differences from one another according to Duncan's Multiple Range Test at $P \leq 0.05$

Along with the other enzymes and metabolites, level of oxidant molecules $\left(\mathrm{H}_{2} \mathrm{O}_{2}\right)$ showed an increasing trend from $3.4 \mu \mathrm{mol} \mathrm{g}{ }^{-1} \mathrm{FW}$ at control conditions to $6.3 \mu \mathrm{mol} \mathrm{g}^{-1}$ FW at $300 \mathrm{mmol} \mathrm{L}^{-1} \mathrm{NaCl}$ conditions. The improtant issue here is that there was no significant difference between 150 - and $300 \mathrm{mmol} \mathrm{L}^{-1} \mathrm{NaCl}$ conditions in that the difference between them in terms of $\mathrm{H}_{2} \mathrm{O}_{2}$ accumulation was negligible indicating that $P$. harmala was able to stabilize the toxic ions till $300 \mathrm{mmol} \mathrm{L}^{-1} \mathrm{NaCl}$ level after $150 \mathrm{mmol} \mathrm{L}^{-1} \mathrm{NaCl}$ concentration (Fig. 6, Table 2).

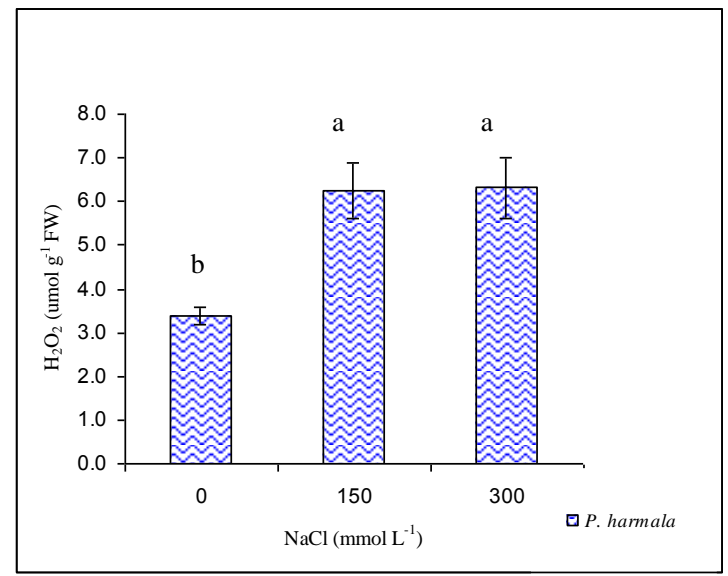

Figure 6. $\mathrm{H}_{2} \mathrm{O}_{2}$ of $\mathrm{P}$. harmala plants at different $\mathrm{NaCl}$ concentrations. Bars indicate the means of threes replicates \pm standard error. Bars with different letters indicate the significant differences from one another according to Duncan's Multiple Range Test at $P \leq 0.05$ 


\section{Determination of ion contents of P. harmala under high $\mathrm{NaCl}$ stress}

The accumulation of $\mathrm{Na}^{+}$and $\mathrm{Cl}^{-}$ions showed an increasing trend along with the decrease of $\mathrm{K}^{+}, \mathrm{Ca}^{++}$and $\mathrm{Mg}^{++}$ions in the leaves of $P$. harmala plants. In $P$. harmala leaves, $\mathrm{Na}^{+}$ion contents increased 19 and 22 times at 150- and $300 \mathrm{mmol} \mathrm{L}^{-1} \mathrm{NaCl}$ conditions, respectively, when compared to those of control plants. $\mathrm{K}^{+}, \mathrm{Ca}^{++}$and $\mathrm{Mg}^{++}$ ions contents were 1.2, 1.5 and 1.3 times were decreases, respectively than those of leaves in the control group. The plants also accumulated $\mathrm{Cl}^{-}$ions 9 times higer under at $300 \mathrm{mmol} \mathrm{L}^{-1} \mathrm{NaCl}$ conditions than those of control plants (Fig. 7A-E, Table 2).

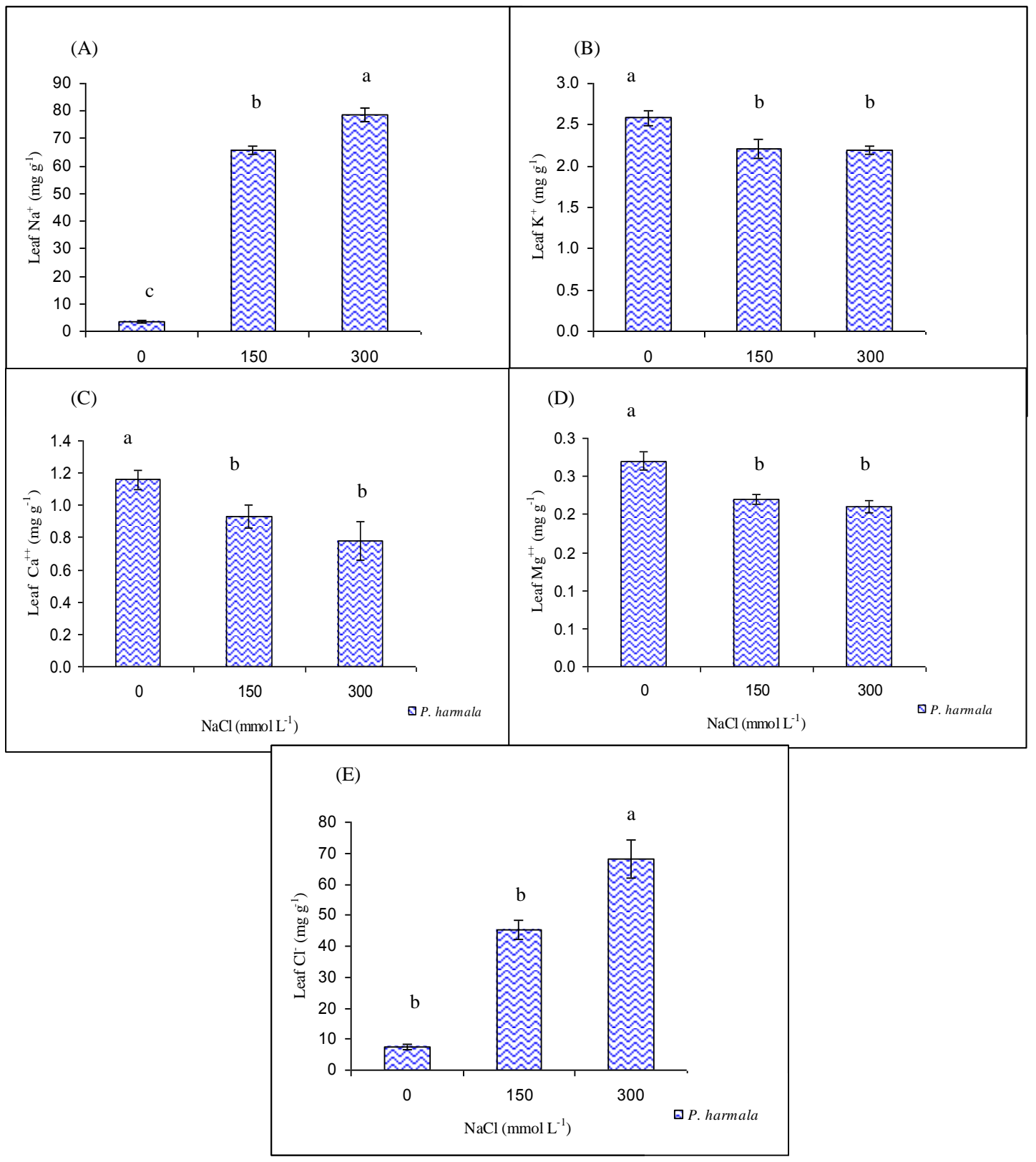

Figure 7. A) $\mathrm{Na}^{+}$; B) $\mathrm{K}^{+}$; C) $\mathrm{Ca}^{++}$; D) $\mathrm{Mg}$ and E) $\mathrm{Cl}^{-}$ions contents of $P$. harmala plants at different $\mathrm{NaCl}$ concentrations. Bars indicate the means of threes replicates \pm standard error. Bars with different letters indicate the significant differences from one another according to Duncan's Multiple Range Test at $P \leq 0.05$ 


\section{Determination of sodium ion removal of $\mathrm{P}$. harmala under high $\mathrm{NaCl}$ stress}

$P$. harmala was determined to be quite effective in removing salt from the soils. It was capable of removing 0.6-, 21.6-, and $28.6 \mathrm{mmol} \mathrm{pot}^{-1} \mathrm{Na}^{+1}$ ion, respectively at $0-$, 150 -, and $300 \mathrm{mmol} \mathrm{L}^{-1}$ in $\mathrm{NaCl}$ conditions. With regard to the mass removal of ions, we estimated that $P$. harmala was capable of removing $404.2 \mathrm{~kg} \mathrm{ha}^{-1}$ at $300 \mathrm{mmol} \mathrm{L}^{-1}$ $\mathrm{NaCl}$ conditions (Fig. $8 A$ and 8 B, Table 2).

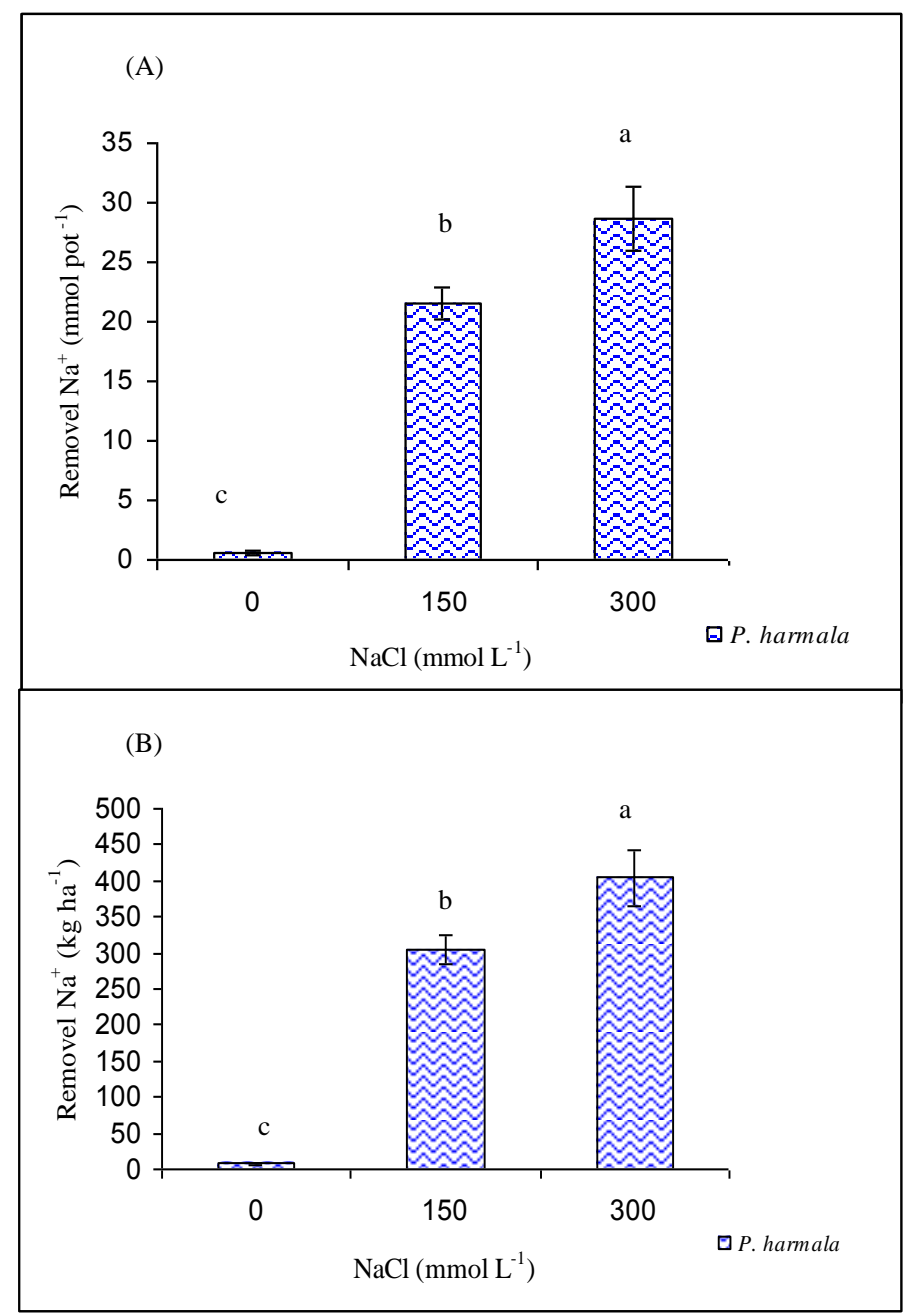

Figure 8. A) The removal of $\mathrm{Na}^{+}$from pots; B) The adjusted removal capacity under field conditions. P. harmala plants at different $\mathrm{NaCl}$ concentrations. Bars indicate the means of threes replicates \pm standard error. Bars with different letters indicate the significant differences from one another according to Duncan's Multiple Range Test at $P \leq 0.05$

Assessment of DNA damage caused by $\mathrm{NaCl}$ showed that $P$. harmala did not show any dose response to $\mathrm{NaCl}$ stress up to $300 \mathrm{mmol} \mathrm{L}^{-1} \mathrm{NaCl}$ level. DNA integrity measurement showed that DNA of the halophyte preserved its uniform shape and was not affected by the toxicity of $\mathrm{NaCl}$ as the other components of cell material. DNA tail length and the percentage of tail DNA did not differ from each other (Fig. 9A, 9B, Table 2). 


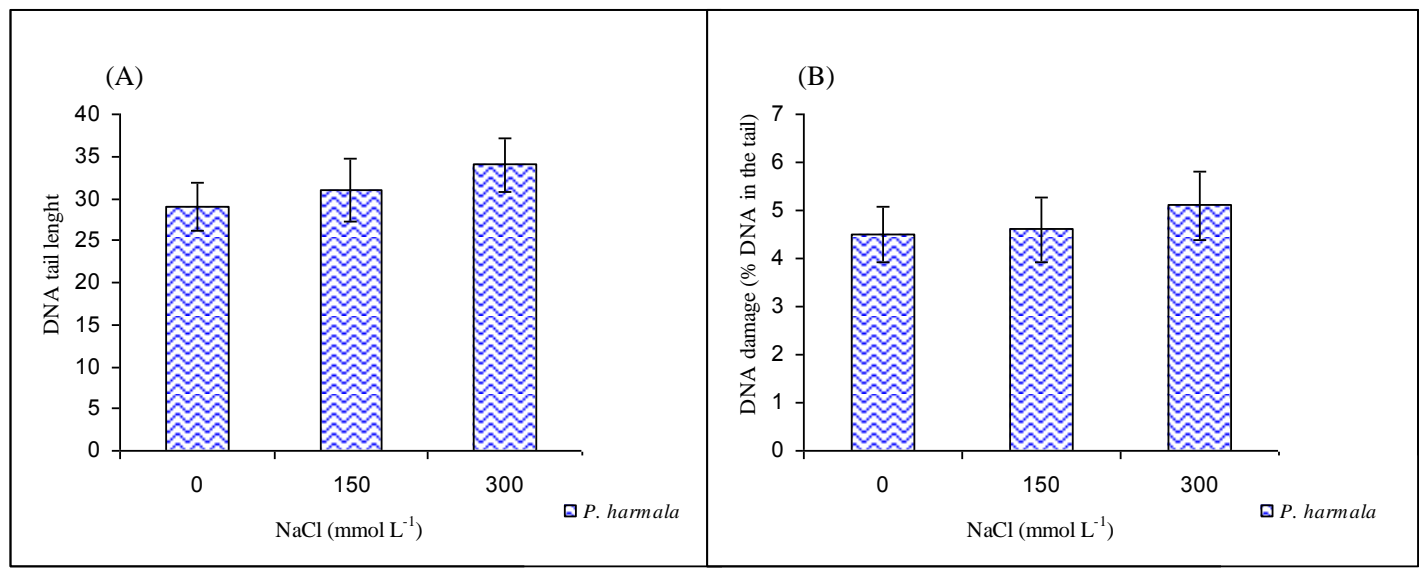

Figure 9. A) DNA tail length $\mathrm{B})$ Percentage of DNA damage of $\mathrm{P}$. harmala at different $\mathrm{NaCl}$ concentrations. Bars indicate the means of threes replicates \pm standard error. Bars with different letters indicate the significant differences from one another according to Duncan's Multiple Range Test at $P \leq 0.05$

\section{Discussion}

Salinity is one of the most important abiotic stress factors reducing crop yields as well as their quality significantly (Okorogbona et al., 2015). Salinity tolerance of plants is achieved by a series of complex and diverse mechanisms; these involve physiological, biochemical and molecular adaptational traits. Halophyte plants, in general, exhibit high salt tolerance, allowing them to survive and thrive under extremely saline conditions (Meng and Sui, 2018). They can tolerate high levels of salt concentrations between from 200 and $1000 \mathrm{mmol} \mathrm{L}^{-1}$ of $\mathrm{NaCl}$ (Flowers and Colmer, 2008). For example, the halophyte Arthrocnemum macrostachyum survives up to $1000 \mathrm{mmol} \mathrm{L}^{-1} \mathrm{NaCl}$ (Khan et al., 2005). Similarly, Debez et al. (2010) applied the Batis maritima, a promising halophyte for sand-dune stabilization and saline-soil reclamation, into saline areas. The plant tolerated high salinity stress up to two-fold of seawater concentration (1000 mmol $\mathrm{L}^{-1} \mathrm{NaCl}$ ). Plant biomass production was maximal at $200 \mathrm{mmol} \mathrm{L}^{-1} \mathrm{NaCl}$.

On the other hand, halophyte plant Carpobrotus acinaciformis grow rapidly at moderate salt concentrations and is able to survive at extreme saline conditions almost close to seawater salt concentrations (Karakas et al., 2019a). In this study, biochemical responses and salt removal capacity of $P$. harmala under moderate and high $\mathrm{NaCl}$ stress were assessed. Evaluation of $P$. harmala was made in terms of growth, chlorophyll (Chl$a$ and Chl- $b$ ), proline, malondialdehyde (MDA) contents along with the activities of, CAT and POX antioxidant enzymes and $\mathrm{H}_{2} \mathrm{O}_{2}$ changes as well as with the determination of mineral contents $\left(\mathrm{Na}^{+}, \mathrm{K}^{+}, \mathrm{Ca}^{++}, \mathrm{Mg}^{++}, \mathrm{Cl}^{-}\right)$. In our findings, the growth of $P$. harmala under $\mathrm{NaCl}$ (150-300 $\mathrm{mmol} \mathrm{L}^{-1}$ ) conditions showed great performance when $\mathrm{FW}$ and DW of the plants were measured. Increases in salt concentrations of the soil positively correlated with the increases of FW and DW of the plant. Similar approaches were made by Suaire et al. (2016) who studied Atriplex halimus and A. hortensis exposed to a solution containing $2 \mathrm{~g} \mathrm{~L}^{-1}$ of $\mathrm{NaCl}$ in a pot experiment for 60 days. The plants were able to accumulate $>50 \mathrm{mg} \mathrm{g}^{-1}$ of DW for $\mathrm{Na}^{+}$ions within the aerial parts of the plants. They concluded that Atriplex halimus and A.hortensis had proming characteristics for phytodesalination of road runoff polluted by deicing salts. 
Chl- $a$ and chl- $b$ contents significantly increased in $P$. harmala leaves with the high $\mathrm{NaCl}$ levels when compared to the control plants growing at no-salt conditions.

Our study showed that $P$. harmala significantly accumulated proline contents to adapt to saline conditions when compared to that of control group. The ability of halophytes to accumulate osmolytes such as proline, glycine betaine, sorbitol, choline-O-sulphate or sugar have been intensively demonstrated in various studies (Tipirdamaz et al., 2006; Arbona et al., 2010; Lugan et al., 2010; Slama et al., 2015). Many physiological measurements of different species emphasize an elevated proline level as a response to salt stress (Szabados and Savoure, 2010; Zhang et al., 2019). In these studies, researchers stated that accumulation of proline prevented the loss of water through evaporation via increasing osmotic pressure. By this way, tolerant plants could survive longer in harsh conditions. In the current experiment, MDA and $\mathrm{H}_{2} \mathrm{O}_{2}$ contents increased along with the increase of $\mathrm{NaCl}$ concentrations as a response to $\mathrm{NaCl}$ toxicity. However, increases in MDA and $\mathrm{H}_{2} \mathrm{O}_{2}$ contents were stabilized after 150 mmol $\mathrm{L}^{-1} \mathrm{NaCl}$ concentration. Accumulations of MDA and $\mathrm{H}_{2} \mathrm{O}_{2}$ are both considered toxic molecules to be determined under stress conditions. They are also positive responses to stress. Therefore, their increases under stress conditions are inevitable, however, the most important issue here is the stabilization of toxic level of molecules after some stages that characterize the plants as tolerant. In our case, this was succeded after $150 \mathrm{mmol} \mathrm{L}^{-1} \mathrm{NaCl}$ conditions. This made $P$. harmala as a good candidate to be employed in saline-affected areas. For example, Amjad et al. (2015) observed an increase of MDA in leaves of Chenopodium quinoa under salt stress. MDA is the measure of damage to membranes and is sometimes regarded as the single most important characteristic to assess the destruction of membranes (Esfandiari et al., 2007). MDA not only directly damages the membranes, but also indirectly causes damage to cell by generating lipid derived radicals that aggravate the oxidative stress (Montillet et al., 2005; AbdElgawad et al., 2016).

Antioxidants play an important role in adapting plants to abiotic stress by detoxifying reactive oxygen species (ROS). Plants evolved different antioxidative mechanisms, among them several enzymatic defense systems are available. The plant defence system includes enzymatic and non-enzymatic antioxidants such as superoxide dismutase (SOD), POX, CAT, glutathione peroxidase (GPX) and ascorbate peroxidase (APX). They act in a sequential concept to scavenge the ROS (Cavalcanti et al., 2007; You and Chan, 2015). In the present study, increased enzyme activities (POX and CAT) played significant roles under $\mathrm{NaCl}$ conditions to detoxify and stabilize the toxic molecules. Similar results have recently been documented by Amjad et al. (2015) in Chenopodium quinoa, and by Podar et al. (2019) in the halophyte Petrosimonia triandra and by Karakas et al. (2019a) in the Carpobrotus acinaciformis.

Apart from the accumulation of antioxidant molecules and osmoprotectants to compensate the toxic effects of $\mathrm{NaCl}$, halophyte plants have remarkably high capacity to accumulate toxic ions in their structures. They can accumulate salts in their various parts such as leaves, stems, roots, and they can force them $\left(\mathrm{Na}^{+}\right.$and $\left.\mathrm{Cl}^{-}\right)$across the tonoplast with highly $\mathrm{Na}^{+} / \mathrm{K}^{+}$selective protein transporters (Radyukina et al., 2007; Guo et al., 2019). This and similar other attributes led researchers to suggest that halophyte plants could be grown in salt-affected soils to remove significant amounts of $\mathrm{Na}^{+}$and $\mathrm{Cl}^{-}$ions through their aerial parts (Qadir et al., 2002; Karakas et al., 2017, 2019b). We noticed that, accumulation of $\mathrm{Na}^{+}$and $\mathrm{Cl}^{-}$ions were remarkably high as compared to the plants in the control group. Decreases in $\mathrm{K}^{+}, \mathrm{Ca}^{++}$and $\mathrm{Mg}^{++}$ions were also noticed in leaves, however, this decrease was stabilized after $150 \mathrm{mmol} \mathrm{L}^{-1} \mathrm{NaCl}$ condition. Similar 
findings were also reported by other workers on Bruguiera parviflora, Ceriops tagal, Halopyrum mocoronatum, Haloxylon recurvum, Suadea fruticose various plants (Parida and Das, 2005; Pan et al., 2016).

We demonstrated that $P$. harmala is quite effective in removing salt from the soils. Similarly, Karakas et al. (2017) observed Salsola soda and Portulaca oleracea removing of salt under soil salinity. This study showed that planting saline soils with $P$. harmala in moderate and high salt conditions might be an effective phytoremediation technique. Since we noticed that $P$. harmala showed great performances up to $300 \mathrm{mmol} \mathrm{L}^{-1} \mathrm{NaCl}$ as it showed at $150 \mathrm{mmol} \mathrm{L}^{-1} \mathrm{NaCl}$ level. We should see the performances at much higher $\mathrm{NaCl}$ concentrations to desalinize heavily salinized soils. This would increase the characteristics of $P$. harmala if pesticide-polluted soils are to be remediated via the use of this plant. Similarly, Yucel et al. (2017) stated that Salicornia europaea removed 426 to $475 \mathrm{~kg}$ salt/ha from the saline area. They stated that Salicornia biomass also provided sufficient amounts of salt to the animals. Otherwise, the senesced litter-fall of Salicornia would contribute to accelerated secondary soil salinization. Availability of these species help us clean up soils characterized with moderate or high salinity. Easy germination and fast growth have been considered as one of the good properties since the fast vegatative growth and accumulation of toxic ions help removing great amount of salt ions from the soil. Management of these species could be one of the novel and holistic approaches for sustainable phytoremediation of saline-affected soils.

Since accumulation of toxic molecules such as $\mathrm{H}_{2} \mathrm{O}_{2}$ was stabilized after $150 \mathrm{mmol} \mathrm{L}^{-}$ ${ }^{1} \mathrm{NaCl}$ conditions up to $300 \mathrm{mmol} \mathrm{L}^{-1} \mathrm{NaCl}$ conditions, the integrity of DNA was noticed to be preserved. It is very well known that high ROS including $\mathrm{H}_{2} \mathrm{O}_{2}$ can damage to DNA via breaking single or double strands (Sharma et al., 2012). At this case, plants may not be able to recover due to damaged or not functional DNA. In our case, DNA preserved its uniform shape up to $300 \mathrm{mmol} \mathrm{L}^{-1} \mathrm{NaCl}$ conditions. With this measurement system, we could also test and measure the capacity of any plants aimed for cleaning up the soils contaminated with salt, pesitices, heavy metals etc.

\section{Conclusion}

This study suggests that $P$. harmala is a salt-tolerant plant. The plant not only tolerates, but needs salt for optimal growth and physiological processes in its natural habitat. Its adaptation mechanisms include physiological, biochemical and molecular adaptation mechanisms. Chlorophyll contents, accumulation of osmolyte proline, lipid peroxidation, activation of an efficient antioxidative system are good sources for antioxidant mechanisms. Understanding of the mechanisms regarding salt adaptation of $P$. harmala could be of great importance, possibly leading to the extension of the arable land by exploiting the phytoremediation capability of this halophyte in the salt area.

In future studies, these characteristics should be well evaluated by measuring toxic components such as superoxide $\left(\mathrm{O}_{2}^{--}\right)$and hydroxyl $\left(\mathrm{OH}^{-}\right)$ions. The salt tolerance characteristics of $P$. harmala should also be evaluated by increasing $\mathrm{NaCl}$ salinity further above $300 \mathrm{mmol} \mathrm{L}^{-1} \mathrm{NaCl}$ conditions to see if much higher salinity is to be tolerated by stabilizing the toxic ion levels. Since $\mathrm{Na}^{+}$and $\mathrm{Cl}^{-}$ions are accumulated in $P$. harmala leaves, salt ions removed from the soil due to the uptake should be measured if further accumulation capacity is achieved. 
Acknowledgments. Biochemical and molecular analyses were performed in the laboratory of Dr. Murat Dikilitas. I thank Dr. Murat Dikilitas for the biochemical and and molecular analyses.

\section{REFERENCES}

[1] AbdElgawad, H., Zinta, G., Hegab, M. M., Pandey, R., Asard, H., Abuelsoud, W. (2016): High Salinity Induces Different Oxidative Stress and Antioxidant Responses in Maize Seedlings Organs. - Frontiers in Plant Science 7: 276.

[2] Acosta-Motos, J. R., Ortuño, M. F., Bernal-Vicente, A., Diaz-Vivancos, P., SanchezBlanco, M. J., Hernandez, J. A. (2017): Plant Responses to Salt Stress: Adaptive Mechanisms. - Agronomy 7(1): 18.

[3] Arnon, D. I. (1949): Copper enzymes in isolated chloroplasts, polyphenol oxidase in Beta vulgaris L. - Plant Physiology 24: 1-15.

[4] Ashraf, M., Harris, P. J. C. (2013): Photosynthesis under stressful environments: An overview. - Photosynthetica 51: 163-190.

[5] Bouyoucos, G. J. (1953): An improved type of soil hydrometer. - Soil Science 76: 377 378.

[6] Carillo, P., Annunziata, M. G., Pontecorvo, G., Fuggi, A., Woodrow, P. (2011): Salinity stress and salt tolerance. - In: Shanker, A. K., Venkateswarlu, B. (eds.) Abiotic Stress in Plants Mechanisms and Adaptations. Rijeka, InTech.

[7] Carillo, P., Cirillo, C., De Micco, V., Arena, C., De Pascale, S., Rouphael, Y. (2019): Morpho-anatomical, physiological and biochemical adaptive responses to saline water of Bougainvillea spectabilis Willd. trained to different canopy shapes. - Agricultural Water Management 212: 12-22.

[8] Cheeseman, J. M. (2015): The evolution of halophytes, glycophytes and crops, and its implications for food security under saline conditions. - New Phytologist 206: 557-570.

[9] Collins, A. R. (2004): The comet assay for DNA damage and repair. - Molecular Biotechnology 26(3): 249-261.

[10] Debez, A., Saadaoui, D., Slama, I., Huchzermeyer, B., Abdelly, C. (2010): Responses of Batis maritima plants challenged with up to two-fold seawater $\mathrm{NaCl}$ salinity. - Journal of plant nutrition and soil science 173: 291-299.

[11] Dikilitas, M. (2003): Effect of salinity \& its interactions with Verticillium albo-atrum on the disease development in tomato (Lycopersicon esculentum Mill.) and lucerne (Medicago sativa \& M. media) plants. - University of Wales, Swansea.

[12] Frison, G., Favretto, D., Zancanaro, F., Fazzin, G., Ferrara, S. D. (2008): A case of betacarboline alkaloid intoxication following ingestion of Peganum harmala seed extract. Forensic Science International 179: 37-43.

[13] Gichner, T., Žnidar, I., Száková, J. (2008): Evaluation of DNA damage and mutagenicity induced by lead in tobacco plants. - Mutation Research 652: 186-190.

[14] Guo, J., Dong, X., Han, G., Wang, B. (2019): Salt-Enhanced Reproductive Development of Suaeda salsa L. Coincided with ion transporter gene upregulation in flowers and increased pollen $\mathrm{K}^{+}$content. - Frontiers in Plant Science 10: 333. doi: $10.3389 /$ fpls.2019.00333.

[15] Gupta, B., Huang, B. (2014): Mechanism of salinity tolerance in plants: physiological, biochemical, and molecular characterization. - International Journal Genomics ID 701596: doi: 10.1155/2014/701596.

[16] Hussain, K., Majeed, A., Nawaz, K., Khizar, H. B., Nisar, M. F. (2009): Effect of different levels of salinity on growth and ion contents of black seeds (Nigella sativa L.). Current Research Journal of Biological Sciences 1: 135-138.

[17] Isayenkov, S. V., Maathuis, F. J. M. (2019): Plant salinity stress: many unanswered questions remain. - Frontiers in Plant Science 10: 80. 
[18] Karakas, S. (2013): Development of tomato growing in soil differing in salt levels and effects of companion plants on same physiological parameters and soil remediation. $\mathrm{PhD}$, University of Harran, Sanliurfa, Turkey.

[19] Karakas, S., Dikilitas, M., Tipırdamaz, R. (2019a): Biochemical and molecular tolerance of Carpobrotus acinaciformis L. halophyte plants exposed to high level of $\mathrm{NaCl}$ stress. Harran Journal of Agricultural and Food Science 23(1): 99-107.

[20] Karakas, S., Dikilitas, M., Aslan, M., Güze, A. N. (2019b): Evaluation of biochemical and physiological responses of salsola spp at their natural habitats. - Harran Journal of Agricultural and Food Science 23(2): 226-233.

[21] Khan, M. A., Ungar, I. A., Showalter, A. M. (2005): Salt stimulation and tolerance in an intertidal stem-succulent halophyte. - Journal of Plant Nutrition 28: 1365-1374.

[22] Konca, K., Lankoff, A., Banasik, A., Lisowska, H., Kuszewski, T., Gozdz, S., Koza, Z., Wojcik, A. (2003): A cross-platform public domain PC image-analysis program for the comet assay. - Mutation Research 534: 15-20.

[23] Munns, R., Tester, M. (2008): Mechanisms of salinity tolerance. - Annual Review of Plant Biology 59: 651-681.

[24] Pan, Y. Q., Guo, H., Wang, S. M., Zhao, B., Zhang, J. L., Ma, Q., Yin, H. J., Bao, A. K. (2016): The photosynthesis, $\mathrm{Na}^{+} / \mathrm{K}^{+}$homeostasis and osmotic adjustment of atriplex canescens in response to salinity. - Frontiers in Plant Science 7: 848.

[25] Pourrut, B., Pinelli, E., Celiz Mendiola, V., Silvestre, J., Douay, F. (2015): Recommendations for increasing alkaline comet assay reliability in plants. - Mutagenesis 30: 37-43.

[26] Richards, L. A. (1954): Diagnosis and improvement of saline and alkali soils. - US Salinity Lab., US Department of Agriculture Handbook 60, California, USA.

[27] Rouphael, Y., Raimondi, G., Lucini, L., Carillo, P., Kyriacou, M. C., Colla, G., Cirillo, V., Pannico, A., El-Nakhel, C., De Pascale, S. (2018): Physiological and metabolic responses triggered by omeprazole improve tomato plant tolerance to $\mathrm{NaCl}$ stress. Frontiers in Plant Science 9: 249.

[28] Sergiev, I., Alexieva, V., Karanov, E. (1997): Effect of spermine, atrazine and combination between them on some en-dogenous protective systems and stress markers in plants. - Comptes Rendus Academie Bulgare Sciences 51: 121-124.

[29] Sharma, P., Jha, A. B., Dubey, R. S., Pessarakli, M. (2012): Reactive oxygen species, oxidative damage, and antioxidative defense mechanism in plants under stressful conditions. - Hindawi Publishing Corporation Journal of Botany, ID 217037. doi: $10.1155 / 2012 / 217037$.

[30] Shrivastava, P., Kumar, R. (2015): Soil salinity: A serious environmental issue and plant growth promoting bacteria as one of the tools for its alleviation. - Saudi Journal of Biological Sciences 22: 123-131.

[31] Simpson, C. R., Franco, J. G., King, S. R., Volder, A. (2018): Intercropping Halophytes to Mitigate Salinity Stress in Watermelon. - Sustainability 10(3): 1-17.

[32] Stuart, J. R., Tester, M., Gaxiola, R. A., Flowers, T. J. (2012): Plants of saline environments. - Access Science http://www.accessscience.com.

[33] Suaire, R., Durickovic, I., Framont-Terrasse, L., Leblain, J. Y., De Rouck, A. C., Simonnot, M. O. (2016): Phytoextraction of $\mathrm{Na}^{+}$and $\mathrm{Cl}^{-}$by Atriplex halimus L. and Atriplex hortensis L.: A promising solution for remediation of road runoff contaminated with deicing salts. - Ecological Engineering 94: 182-189.

[34] Wanntorp, L., Ronse De Craene, L. P. (2011): Flowers on the Tree of Life. - In: Gower, D. J. (ed.) The Systematics Association Special Volume Series. Cambridge University Pres, UK.

[35] You, J., Chan, Z. (2015): ROS regulation during abiotic stress responses in crop plants. Frontiers in Plant Science 6: 1092.

[36] Yucel, C., Farhan, M. J., Khairo, A. M., Ozer, G., Cetin, M., Ortas, I., Islam, K. R. (2017): Evaluating Salicornia as a potential forage crop to remediate high groundwater- 
table saline soil under continental climates. - International Journal of Plant and Soil Science 16(6): 1-10.

[37] Zakharin, A. A., Panichkin, L. A. (2009): Glycophyte salt resistance. - Russian Journal of Plant Physiology 56: 94-103.

[38] Zhang, X., Liu, L., Chen, B., Qin, Z., Xiao, Y., Zhang, Y., Yao, R., Liu, H., Yang, H. (2019): Progress in understanding the physiological and molecular responses of Populus to salt stress. - International Journal of Molecular Sciences 20(6): 1312. 